\title{
Characteristics of selected pork muscles 45 min and 24 h post mortem
}

\author{
Josef Kameník, Alena Saláková, Ladislav Kašpar \\ University of Veterinary and Pharmaceutical Sciences Brno, Faculty of Veterinary Hygiene and Ecology, \\ Department of Meat Hygiene and Technology, Brno, Czech Republic
}

Received July 17, 2017

Accepted May 15, 2018

\begin{abstract}
The muscles of the pork topside - musculus adductor (AD) and $\mathrm{m}$. semimembranosus (SM), and of the silverside $-\mathrm{m}$. biceps femoris (BF) and $\mathrm{m}$. semitendinosus (ST) were analysed and their properties compared with the $\mathrm{m}$. longissimus thoracis (LT) and $\mathrm{m}$. supraspinatus (SS) muscles. Colour (CIE L*a*b*), D/L-lactic acid content, and $\mathrm{pH}$ values were measured $45 \mathrm{~min}$ and $24 \mathrm{~h}$ post mortem. The basic chemical composition of muscles was analysed $24 \mathrm{~h}$ after slaughtering. A significant correlation $(\mathrm{r}=-0.61, P<0.001)$ was found between the $\mathrm{pH}$ values and the level of lactic acid 45 min post mortem, though not $24 \mathrm{~h}$ after slaughter $(\mathrm{r}=-0.25, P>0.05)$. The results confirmed that a direct comparison cannot be made between the fall in $\mathrm{pH}$ values in meat and the increase in the level of lactic acid. The lightness $\mathrm{L}^{*} 24 \mathrm{~h}$ post mortem was higher $(P<0.05)$ in $\mathrm{AD}, \mathrm{BF}, \mathrm{ST}$ and LT muscles than those in samples measured $45 \mathrm{~min}$ after slaughter. The toughest muscle was biceps femoris, with a mean value of shear force of $90.5 \mathrm{~N}$. The differences in shear force between the individual analysed muscles were significant $(P<0.05)$. There were significant differences in the intramuscular fat content between the topside and silverside muscles $(P<0.05)$. The results of the present study are of value to meat producers who might intend to substitute these parts of the leg with one another during the production, particularly in the case of wholemuscle meat products.
\end{abstract}

Lactic acid, pH value, colour, shear force, protein content, intramuscular fat

Colour, tenderness, and water-binding capacity are considered the most important characteristics of fresh meat (Hughes et al. 2014). England et al. (2015) believe the quality of pork meat to be determined by two basic factors - the speed at which the $\mathrm{pH}$ falls in the muscles and the final $\mathrm{pH}$ value attained post mortem.

Joo et al. (2013) defined three groups of meat traits that are of interest to the consumer -appearance quality traits, eating quality traits, and reliance quality traits. These characteristics are particularly important in the retail during the selection and purchase of meat cuts by consumer. In production, producers prioritise properties that guarantee the uniformity of the products they produce. Colour, or more accurately the balance of colour tone of contiguous muscles (meat) in whole-muscle meat products (and hams in particular), is also important, in addition to the fore-mentioned features such as the water binding capacity and tenderness (McKeith and Pringle 2013).

The proportion of fat and, in particular, protein, is also important. The legislation of many countries stipulates limits defining the minimum content of pure muscle protein in selected meat products (DLB 2010) or minimum values for the water : protein ratio (ÖLB 2012). The chemical composition of meat is important in these cases with regard to the balance between the content of total (crude) protein, collagen and fat. The speed and extent of the fall in $\mathrm{pH}$ values and the final $\mathrm{pH}$ value can, on the other hand, influence the colour of the meat (Ruusunen et al. 2012). 
Meat from the legs, particularly the topside and silverside, is used in the production of premium cooked hams. The topside is composed largely of two muscles, $\mathrm{m}$. adductor (AD) and $\mathrm{m}$. semimembranosus (SM), and the silverside of $\mathrm{m}$. biceps femoris (BF) and $\mathrm{m}$. semitendinosus (ST). Each muscle has a specific role to play in the body. The unique characteristic of skeletal muscle is its diversity resulting from the formation of the individual muscles, the type of muscle fibres, and the composition and heterogeneity of individual fibres. No two muscles in the body are identical (Karlsson et al. 1999). What is, on one hand, crucial to the life of the individual, i.e. the heterogeneity of muscle tissue, is, on the other hand, disadvantageous to producers in their effort to ensure the standard production of particular types of meat products, and whole-muscle products in particular. A great many studies considering selected properties of pork meat (differences in fibre type distribution, myofibrillar degradation, colour, tenderness, $\mathrm{pH}$ value etc.) have been published in the scientific literature over the last twenty years (e.g. Christensen et al. 2004; Melody et al. 2004; Gil et al. 2008; Choe et al. 2009; Purchas et al. 2009; Choi et al. 2013; Realini et al. 2013). The majority of these works have studied in detail just a small number of muscles, such as the $\mathrm{m}$. longissimus thoracis, $\mathrm{m}$. semimembranosus or $\mathrm{m}$. semitendinosus. To date, there has been no detailed analysis of the technologically important muscles in the leg.

The aim of this study was to analyse and compare the topside (AD and SM) and silverside (BF and ST) muscles of slaughter pigs.

\section{Materials and Methods}

Meat samples

Samples of pork meat were obtained from the slaughterhouse of the University of Veterinary and Pharmaceutical Sciences in Brno. Gilts of the Danish-Norwegian breed Topigs were used for the purposes of assessment $(\mathrm{n}=9)$, at a slaughter weight of $100 \pm 10 \mathrm{~kg}$. The pigs came from a farm within $50 \mathrm{~km}$ of the place of slaughter. The animals were transported to the slaughterhouse 2-3 h before slaughter. Stunning was performed with an electric current (head-only stunning), bleeding in the hanging position. Following halving, the left side was cut into individual parts immediately; the right side was chilled at a temperature of $2{ }^{\circ} \mathrm{C}$ and cut up the following day $24 \mathrm{~h}$ post mortem.

The following muscles were selected for evaluation: AD, SM, ST, BF, SS and LT. Colour in the CIE L*a*b system, the D/L-lactic acid content and $\mathrm{pH}$ values were measured $45 \mathrm{~min}$ and $24 \mathrm{~h}$ post mortem. Other properties were evaluated $24 \mathrm{~h}$ post mortem. A total of 54 samples of muscles were analysed.

The $\mathrm{pH}$ value and lactic acid analysis

The $\mathrm{pH}$ values were measured with a Double Pore needle probe (Hamilton, Switzerland) on a 340i WTW pH-meter (WTW, Germany).

D/L-lactic acid was determined using an enzymatic test kit (MEGAZYME, Ireland). The quantification of D-lactic acid required two enzyme reactions. In the first reaction catalysed by D-lactate dehydrogenase (D-LDH), D-lactic acid (D lactate) was oxidised to pyruvate in the presence of nicotinamide adenine dinucleotide $\left(\mathrm{NAD}^{+}\right)$, and the product, pyruvate, trapped by the conversion of pyruvate to D-alanine and 2-oxoglutarate with the enzyme D-glutamate-pyruvate transaminase (D-GPT) in the presence of a large excess of D-glutamate, while the NADH formed was quantified by measuring the absorbance at $340 \mathrm{~nm}$.

In a similar set of reactions, L-lactic acid (L-lactate) was oxidised to pyruvate by L-lactate dehydrogenase (L-LDH) in the presence of nicotinamide adenine dinucleotide $\left(\mathrm{NAD}^{+}\right)$, and the product, pyruvate, trapped by the conversion of pyruvate to D-alanine and 2-oxoglutarate with the enzyme D-glutamate-pyruvate transaminase (D-GPT) in the presence of a large excess of D-glutamate. The NADH formed was quantified by measuring the absorbance at $340 \mathrm{~nm}$ (MEGAZYME 2011). All samples were measured in triplicate.

Instrumental analysis

Colour was measured by the CIE L*a*b* system using a Minolta CM 2600d (Konica Minolta, Japan). A measuring area of $8 \mathrm{~mm}$, illuminant D65 and $10^{\circ}$ standard observer were used. The instrument was standardised using a standard white plate. CIE L* - lightness, $a^{*}$ - redness, $b^{*}$ - yellowness were measured. Five independent subsamples were measured for each sample. 
Raw samples were tested by Warner-Bratzler test (WB) using the Instron Universal Testing Machine (model 5544) (Instron Corporation, England). Samples of $2.5 \times 2.5 \times 2.0 \mathrm{~cm}$ and a perpendicular arrangement were used for the WB test. Force time curves were recorded at a crosshead speed of $50 \mathrm{~mm} \cdot \mathrm{min}^{-1}$. Maximum shear force was evaluated (WBSF) from five replicates from each sample.

\section{Chemical analysis}

A drying method (ISO $1442: 1997$ ) at $103 \pm 2{ }^{\circ} \mathrm{C}$ for a period of $24 \mathrm{~h}$ was used for the determination of the dry matter content. The samples were weighed after cooling and the dry matter content was calculated. The fat content was determined using a SOXTEC instrument (TECATOR, Sweden). Samples were left in the drier for $3 \mathrm{~h}$ at $135 \pm 2{ }^{\circ} \mathrm{C}$ and extracted by the extraction agent (diethyl ether) in the instrument. The collagen content was determined spectrophotometrically at a wavelength of $550 \mathrm{~nm}$ in a GENESYS ${ }^{\mathrm{TM}} 6$ spectrophotometer (Thermo Electron Corporation, USA) as the quantity of 4-hydroxyproline. The content of hydroxyproline was obtained from the calibration curve and converted into the collagen content $(f=8)$. Crude proteins were determined after subsequent conversion of organic nitrogen to inorganic nitrogen in a KJELTEC instrument (TECATOR, Sweden) by the Kjeldahl method. A factor of 6.25 was used for the conversion of the nitrogen content into the protein content. Pure muscle proteins were determined following the precipitation of non-protein N-substances by hot tannin and subsequent conversion of organic nitrogen into inorganic nitrogen in a KJELTEC instrument (TECATOR, Sweden) by the Kjeldahl method. A factor of 6.25 was used for the conversion of the nitrogen content into the protein content. Two independent subsamples of each muscle were used also for determining the dry matter, fat content, and protein content.

\section{Statistical analysis}

The results of the instrumental and chemical analyses are reported as mean values \pm standard deviation (SD). Statistical data analyses were conducted using the statistical program STATISTICA 7 CZ (StatSoft, Prague, Czech Republic). ANOVA (Tukey's test) was used for the determination of significant differences between the groups of samples. Correlation analyses among indicators were performed using Pearson correlation coefficients. Significance levels of $P<0.05, P<0.01$ and $P<0.001$ were used.

\section{Results}

The $\mathrm{pH}$ value and lactic acid content

Mean $\mathrm{pH}_{45}$ values ranging from 6.35 (AD) to 6.03 (ST) were found in this study (Table 1). A level of D/L-lactic acid ranging from 82 (AD) to 302 (SS) $\mu \mathrm{mol}^{-1} \mathrm{~g}^{-1}$ of dry matter, with the mean values between 141 (BF) and 209 (SS) $\mu \mathrm{mol} \cdot \mathrm{g}^{-1}$ of dry matter, was found in the tested muscles $45 \mathrm{~min}$ after slaughter (Table 1). Over the next $24 \mathrm{~h}$, the $\mathrm{D} / \mathrm{L}$-lactic acid content increased $(P<0.05)$ in AD, BF, ST and LT muscles. There were no significant differences in the lactic acid level between individual muscles $24 \mathrm{~h}$ post mortem.

\section{Instrumental indicators}

The instrumental analysis of meat colour showed that the $L^{*}$ values increased with the falling $\mathrm{pH}$ in the muscles. The $\mathrm{L}^{*}$ value increased $(P<0.05)$ in $\mathrm{LT}, \mathrm{AD}, \mathrm{BF}$ and $\mathrm{ST}$ muscles during the $24 \mathrm{~h}$ post mortem, but not in SS and SM $(P>0.05)$. Significant correlations were found between $\mathrm{pH}$ values and the value of lightness $\mathrm{L}^{*} 45$ min post mortem $(\mathrm{r}=-0.33$, $P<0.05)$ and $24 \mathrm{~h}$ post mortem $(\mathrm{r}=-0.56, P<0.001)$.

Significant correlations were found $24 \mathrm{~h}$ after slaughter between the values of $\mathrm{pH}$ and $\mathrm{a}^{*}(\mathrm{r}=0.45 ; P<0.05)$, and also between the levels of lactic acid and indicator $\mathrm{a}^{*}(\mathrm{r}=-0.49 ; P<0.001)$. A lower value of significant correlations was demonstrated $45 \mathrm{~min}$ post mortem between the values of $\mathrm{pH}$ and $\mathrm{a}^{*}(\mathrm{r}=-0.33, P<0.05)$ and also between the values of $\mathrm{pH}$ and indicator $\mathrm{b}^{*}(\mathrm{r}=-0.32 ; P<0.01)$.

The highest mean values of $\mathrm{a}^{*}$ were measured after slaughter in SS, the lowest in LT $(P<0.05)$. In the legs muscles, the values $45 \mathrm{~min}$ after slaughter were lowest in $\mathrm{AD}$ and highest in ST $(P<0.05)$. The mean a*values $24 \mathrm{~h}$ post mortem had risen in the LT muscle $(P<0.05)$, but not in the muscles AD SM and BF $(P>0.05)$. The increase in the $\mathrm{b}^{*}$ values after $24 \mathrm{~h}$ was significant $(P<0.05)$ in muscles with the exception of SS $(P>0.05)$. The shear force value (WBSF) expresses the reciprocal value of 


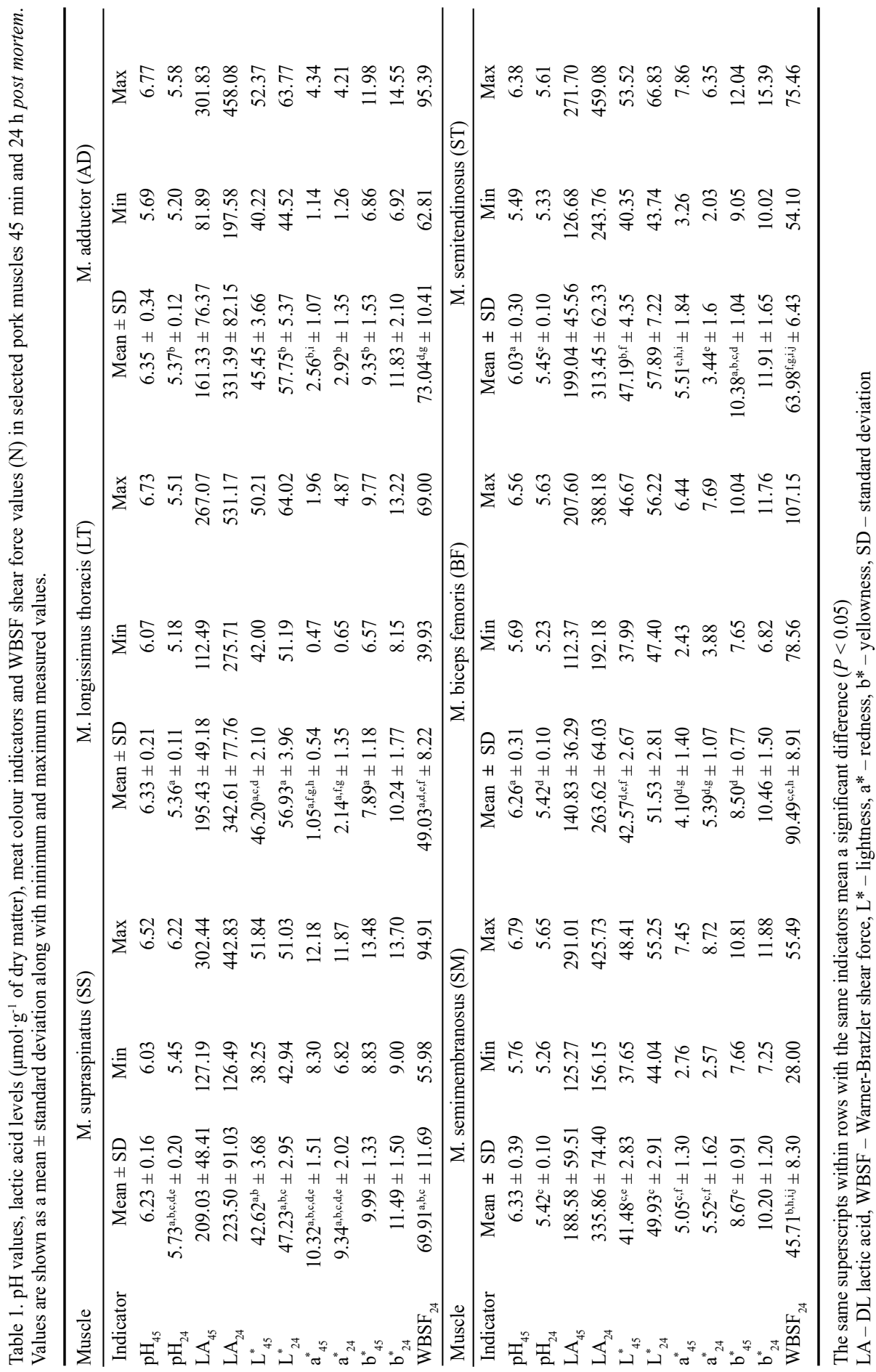




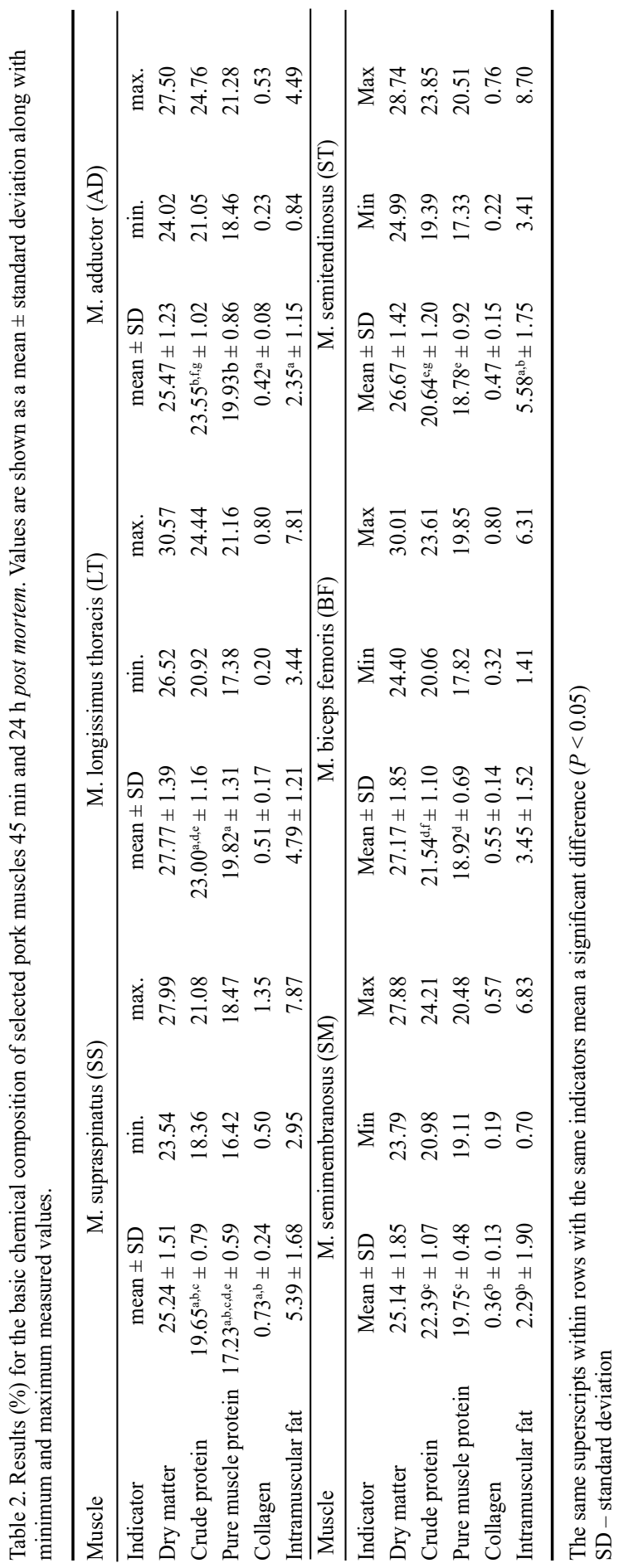

tenderness of the meat. In this regard, the toughest muscle $24 \mathrm{~h}$ post mortem was the BF, with a mean value of $90.5 \mathrm{~N}$, followed by $\mathrm{AD}(73.0 \mathrm{~N})$ and $\mathrm{SS}(69.9 \mathrm{~N})$. The differences in the value of WBSF between the individual analysed muscles were significant $(P<0.05$; Table 1).

Chemical composition of pork muscles

The basic chemical composition of the analysed pork muscles is given in Table 2. The samples did not differ in the dry matter content $(P>0.05)$. The highest content of crude proteins was measured in the $\mathrm{AD}$ (mean value $23.6 \%$ ) and LT $(23.0 \%)$ muscles. In the leg muscles, significant differences $(P<0.05)$ were found between AD and $\mathrm{BF}$, and between $\mathrm{AD}$ and $\mathrm{ST}$ in the crude protein content. There were no significant differences $(P>0.05)$ in the proportions of pure muscle proteins (myofibrillar and sarcoplasmic proteins) or collagen content between leg muscles (Table 2).

The leanest muscles with the lowest proportion of intramuscular fat were both of the muscles of the topside (AD, 2.4\%; SM, 2.3\%). The differences in the proportion of fat between the two topside muscles and the ST were significant $(P<0.05)$.

\section{Discussion}

Values of $\mathrm{pH}_{45}$ of less than 5.90 were measured in a number of individual samples of all four leg muscles which can be considered a manifestation of the PSE (pale, soft, exudative meat) type defect (Feiner 2006). $\mathrm{pH}$ values $<5.90$ were found 45 min post mortem in one case in the AD muscle, in two cases in the BF muscle, and in 
three animals in the case of the SM and ST muscles (data not shown). The lowest $\mathrm{pH}_{45}$ value of 5.69 was measured in the AD muscle, with the lowest $\mathrm{pH}$ value in the $\mathrm{SM}$ muscle also being detected in the same carcass. Values of $\mathrm{pH}_{45}<5.90$ were also found in the $\mathrm{BF}$ and ST muscles from the same animal (BF: 5.88; ST: 5.77), though these were not the lowest values recorded. The same animal also had the lowest measured $\mathrm{pH}_{45}$ value of all the LT muscles (6.07).

The mean $\mathrm{pH}$ values ranging from 5.37 (AD) to 5.45 (ST) were found in the leg muscles $24 \mathrm{~h}$ post mortem. These values are lower than those reported in literature. Warner et al. (1993) found $\mathrm{pH}_{\mathrm{u}}$ values of $5.76(\mathrm{SM}), 5.82(\mathrm{BF})$, and $5.86(\mathrm{ST})$ in the muscles of 19 carcasses. The mean $\mathrm{pH}_{u}$ value in the $\mathrm{SS}$ shoulder muscle was 5.97. Christensen et al. (2004) measured pH values of 5.77 in the ST and 5.61 in the SM $24 \mathrm{~h}$ after slaughter. Gil et al. (2008) determined a $\mathrm{pH}_{\mathrm{u}}$ value of 5.49-5.55 in the SM, whereas Tomović et al. (2008) found a mean $\mathrm{pH}_{24}$ value of 5.70 in the same muscle. The results closest to the values found in our study were those of the authors Voutila et al. (2007) who measured a mean $\mathrm{pH}_{u}$ value of 5.45 in a population of 14 pigs in Finland, though 13 gilts from Ireland had a $\mathrm{pH}_{\mathrm{u}}$ value of 5.70 in the same muscle.

The accumulation of lactate is a good measure of the extent and level of glycolysis. It is, however, deceptive to use the level of lactate directly to determine the fall in the $\mathrm{pH}$ value in the muscles (Ferguson and Gerrard 2014). A significant correlation $(\mathrm{r}=-0.61, P<0.001)$ was found between $\mathrm{pH}$ values and the level of lactic acid $45 \mathrm{~min}$ post mortem, though not $24 \mathrm{~h}$ after slaughter $(\mathrm{r}=-0.25, P>0.05)$. The results of this study confirmed that a direct comparison cannot be made between the fall in $\mathrm{pH}$ values in the meat and the increase in the level of lactic acid.

Biochemical processes in the muscle tissue post mortem have an effect on the dispersion of light and, thereby, on the indicators of meat colour. The relocation of liquid occurs in the muscle fibres post mortem as a result of the fall in $\mathrm{pH}$ values. The dispersion and reflection of light also increases. The result is an increased value of lightness (Hughes et al. 2014).

In the leg muscles $24 \mathrm{~h}$ after slaughter, mean $\mathrm{L}^{*}$ values ranging between 57.9 and 49.9 were found. Similar values were also found in the SM by Purchas et al. (2009) and Voutila et al. (2007). Warner et al. (1993), however, found lower $\mathrm{L}^{*}$ values $24 \mathrm{~h}$ after slaughter in selected leg muscles (ST: 52.6; SM: 46.4; BF: 45.6). Tomović et al. (2008) found mean $\mathrm{a}^{*}$ values of 9.21 and $\mathrm{b}^{*}$ of 4.68 in SM muscles $24 \mathrm{~h}$ post mortem with the use of a conventional method of chilling. Ruusunen et al. (2012) measured mean a*values of 7.0-8.4 in LT, whereas Realini et al. (2013) found an a value of 7.53 in LT.

Meat tenderness is determined by the amount and solubility of the connective tissue, shortening of sarcomeres during rigor development, post mortem proteolysis of myofibrillar and myofibrillar-associated proteins and the amount of intramuscular fat (Warner et al. 2010). The $\mathrm{pH}$ of muscles is reduced early post mortem and it affects the shrinkage of myofibrils (Huff-Lonergan and Lonergan, 2005). In the present study, the toughest muscle was the BF muscle, the most tender was the SM muscle. Comparing the $\mathrm{pH}$ values between the two above mentioned muscles, there were no significant differences in $\mathrm{pH}_{45}$ and the values of $\mathrm{pH}_{24}$ were the same for both muscles. In the intramuscular fat content the differences between the BF and SM muscles were not significant. Likewise, there were no significant differences in the collagen content. The WBFS values of the assessed muscles were apparently influenced by several factors depending on the functional status and chemical composition of the individual muscles.

Kim et al. (2008) published a detailed analysis of the chemical composition of 21 pork muscles. They studied muscles obtained from 10 hybrids (5 gilts and 5 barrows) with a mean carcass weight of $86.00 \pm 5.68 \mathrm{~kg}$. The proportion of dry matter determined in the muscles was lower than that found in the present study. Nevertheless, the topside muscles still showed a lower proportion of dry matter (AD 23.9\%; SM 24.5\%) than the BF $(25.1 \%)$ 
and ST $(25.7 \%)$ muscles. The silverside muscles contained a lower proportion of protein (BF 19.8\%; ST 18.8\%) compared to the topside muscles (AD 21.3\%; SM 20.9\%). The fattiest muscle in the leg was, in agreement with the present study, the ST $(6.1 \%)$. The muscles of the topside had a low proportion of fat (AD 1.7\%; SM 3.1\%). Voutila et al. (2007) found a practically similar proportion of collagen in the SM $(0.4 \%)$, though a lower content in the LT $(0.25-0.31 \%)$ compared to the present study $(0.51 \%)$. A proportion of fat of $2.31 \%$ and $2.52 \%$ and a total protein content of $22.4 \%$ and $23.6 \%$ were found in the SM of pigs fattened extensively and intensively in New Zealand (Purchas et al. 2009). The given values correspond to the proportions found in the present study. Ruusunen et al. (2012) measured a mean proportion of total proteins in the LT between 21.8 and $22.9 \%$ and a mean proportion of dry matter ranging from 25.9 to $26.7 \%$ in various breeds in Scandinavia. Realini et al. (2013) found a mean percentage of dry matter of $24.0 \%$, and proportions of total proteins of $21.0 \%$, collagen $0.9 \%$ and fat $2.3 \%$ in ST. The mean values found in the LT were $25.9 \%$ (dry matter), $24.4 \%$ (total proteins), $0.5 \%$ (collagen) and $1.0 \%$ (fat).

Although the differences in the chemical composition of the muscles of the topside and silverside in present study are not particularly large, they should be given due consideration by producers if they intend to substitute these parts of the leg with one another during the production of meat products, as this could affect the proportion of fat or pure muscle proteins in final products, particularly in the case of whole-muscle meat products.

\section{Acknowledgement}

The authors thank the Czech Technology Platform for Foodstuffs for financial support of the research conducted at the Faculty of Veterinary Hygiene and Ecology of the University of Veterinary and Pharmaceutical Sciences Brno.

\section{References}

Choe JH, Choi YM, Lee SH, Nam YJ, Jung YC, Park HC, Kim YY, Kim BC 2009: The relation of blood glucose level to muscle fiber characteristics and pork quality traits. Meat Sci 83: 62-67

Choi YM, Nam KW, Choe JH, Ryu YC, Wick MP, Lee K, Kim BC 2013: Growth, carcass, fiber typ, and meat quality characteristics in Large White pigs with different live weights. Livest Sci 155: 123-129

Christensen M, Henckel P, Purslow PP 2004: Effect of muscle type on the rate of post-mortem proteolysis in pigs. Meat Sci 66: 595-601

DLB 2010: Leitsätze für Fleisch und Fleischerzeugnisse. Neufassung vom 25.11.2015 (BAnz AT 23.12.2015 B4, GMB1 2015 S. 1357) (in German). http://www.bmel.de/SharedDocs/Downloads/Ernaehrung/ Lebensmittelbuch/LeitsaetzeFleisch.pdf?_blob=publicationFile

England EM, Matarneh SK, Scheffler TL, Wachet C, Gerrard DE 2015: Altered AMP deaminase activity may extend postmortem glycolysis. Meat Sci 102: 8-14

Feiner G 2006: Meat products handbook. Practical science and technology. CRC Press, Boca Raton, Florida, USA. 672 p.

Ferguson DM, Gerrard DE 2014: Regulation of post-mortem glycolysis in ruminant muscle. Anim Product Sci 54: 464-481

Gil M, Delday MI, Gispert M, Font i Furnols M, Maltin CM, Plastow GS, Klont R, Sosnicki AA, Carrión D 2008: Relationships between biochemical characteristics and meat quality of longissimus thoracis and semimembranosus muscles in five porcine lines. Meat Sci 80: 927-933.

Huff-Lonergan E, Lonergan SM 2005: Mechanisms of water-holding capacity of meat: The role of postmortem biochemical and structural changes. Meat Sci 71: 194-204.

Hughes JM, Oiseth SK, Purslow PP, Warner RD 2014: A structural approach to understanding the interactions between colour, water-holding capacity and tenderness. Meat Sci 98: 520-532

ISO 144. 1997: Meat and meat products: Determination of moisture content (Reference method). Prague: Czech office for standards, metrology and testing (in Czech).

Joo ST, Kim GD, Hwang YH, Ryu YC 2013: Control of fresh meat quality through manipulation of muscle fiber characteristics. Meat Sci 95: 828-836

Karlsson AH, Klont RE, Fernandez X 1999: Skeletal muscle fibres as factors for pork quality. Livest Product Sci 60: $255-269$ 
Kim JH, Seong PN, Cho SH, Park BY, Hah KH, Yu LH, Lim DG, Hwang IH, Kim DH, Lee JM, Ahn CN 2008 : Characterization of Nutritional Value for Twenty-one Pork Muscles. Asian-Aust J Anim Sci 21: 138-143

McKeith RO, Pringle TD 2013: Quality attributes and color characteristics in three-piece boneless hams. Meat Sci 95: 59-63

MEGAZYME 2011: D-lactic acid and L-lactic acid assay procedure K-DLATE 05/11. Megazyme International Ireland Limited

Melody JL, Lonergan SM, Rowe J, Huiatt TW, Mayes MS, Huff-Lonergan E 2004: Early postmortem biochemical factors influence tenderness and water-holding capacity of three porcine muscles. J Anim Sci 82: 1195-1205

ÖLB 2012: Österreichisches Lebensmittelbuch; IV. Auflage Codexkapitel / B 14 / Fleisch und Fleischerzeugnisse (in German) https://www.verbrauchergesundheit.gv.at/lebensmittel/buch/codex/B_14_Fleisch_und Fleischerzeugnisse 2.pdf?62f486

Purchas RW, Morel PCH, Janz JAM, Wilkinson BHP 2009: Chemical composition characteristics of the longissimus and semimembranosus muscles for pigs from New Zealand and Singapore. Meat Sci 81: 540-548

Realini CE, Vénien A, Gou P, Gatellier P, Pérez-juan M, Danon J, Astruc T 2013: Characterization of longissimus thoracis, semitendinosus and masseter muscles and relationships with technological quality in pigs. 1. Microscopic analysis of muscles. Meat Sci 94: 408-416

Ruusunen M, Puolanne E, Sevon-Aimonen ML, Partanen K, Voutila L, Niemi J 2012: Carcass and meat quality traits of four different pig crosses. Meat Sci 90: 543-547

Tomović VM. Petrović LS, Džinić NR 2008: Effects of rapid chilling of carcasses and time of deboning on weight loss and technological quality of pork semimembranosus muscle. Meat Sci 80: 1188-1193

Voutila L, Mullen AM, Ruusunen M, Troy D, Puolanne E 2007: Thermal stability of connective tissue from porcine muscles. Meat Sci 76: 474-480

Warner RD, Kauffman RG, Russell RL 1993: Quality attributes of major porcine muscles: a comparison with the longissimus lumborum. Meat Sci 33: 359-372

Warner RD, Greenwood PL, Pethick DW, Ferguson DM 2010: Genetic and environmental effects on meat quality. Meat Sci 86: 171-183 